PEDAGOGIA : Jurnal Ilmu Pendidikan

\title{
KONTRIBUSI MINAT BELAJAR DAN KECERDASAN EMOSIONAL TERHADAP HASIL BELAJAR STATISTIK MAHASISWA
}

\author{
Laras Oktaviani, Nirmala Tari \\ Sekolah Tinggi Ilmu Ekonomi Triatma Mulya \\ larasoktaviani999@gmail.com
}

\begin{abstract}
Abstrak
Penelitian ini bertujuan untuk mengetahui kontribusi minat belajar dan kecerdasan emosional terhadap hasil belajar statistik mahasiswa D III Perhotelan semester 6 Sekolah Tinggi Pariwisata Triatma Jaya tahun pelajaran 2017/2018. Populasi penelitian ini berjumlah 77 orang. Teknik pengambilan sampel dalam penelitian ini menggunakan sampel jenuh dimana semua anggota populasi dijadikan sampel penelitian. Data minat belajar dan kecerdasan emosional dikumpulkan dengan menggunakan kuesioner model skala likert. Sedangkan hasil belajar statistik dikumpulkan dengan menggunakan tes hasil belajar berupa soal pilihan ganda. Data yang diperoleh dianalisis secara statistik dengan analisis regresi linier berganda. Temuan penelitian ini adalah: (1) terdapat kontribusi yang signifikan minat belajar terhadap hasil belajar statistik mahasiswa D III Perhotelan semester 6 Sekolah Tinggi Pariwisata Triatma Jaya tahun pelajaran 2017/2018 dengan kontribusi sebesar 52,9\%; (2) terdapat kontribusi yang signifikan kecerdasan emosional terhadap hasil belajar statistik mahasiswa D III Perhotelan semester 6 Sekolah Tinggi Pariwisata Triatma Jaya tahun pelajaran 2017/2018 dengan kontribusi sebesar 36,8\%; (3) secara bersama-sama terdapat kontribusi yang signifikan minat belajar dan kecerdasan emosional terhadap hasil belajar statistik mahasiswa D III Perhotelan semester 6 Sekolah Tinggi Pariwisata Triatma Jaya tahun pelajaran 2017/2018 dengan kontribusi sebesar $66,1 \%$.
\end{abstract}

Kata Kunci: Minat Belajar; Kecerdasan Emosional; Hasil Belajar Statistik

\begin{abstract}
This study aims to know the contribution of interest in learning and emotional intelligence to the students' statistical learning outcomes the sixth semester D III students in Triatma Jaya Institute of Tourism in academic year 2017/2018. The population of this study was 77 people. The sampling technique in this study used a saturated sample where all members of the population were sampled. The interest data and emotional intelligence were collected by using Likert scale model questionnaire. While the statistical learning outcomes were collected using the learning result test in the form of multiple-choice questions. The data obtained were analyzed statistically with multiple linear regression analysis. The findings of this research are: (1) there is a significant contribution of interest in learning to the statistical learning outcomes of the sixth semester D III students in Triatma Jaya Institute of Tourism in academic year 2017/2018 with contribution of 52,9\%; (2) there is a significant contribution of emotional intelligence to the statistical learning outcomes of the sixth semester D III students in Triatma Jaya Institute of Tourism in academic year 2017/2018 with contribution of 36,8\%; (3) all at once there is a significant contribution of interest in learning and emotional intelligence to the students' statistical learning outcomes of the sixth semester D III students in Triatma Jaya Institute of Tourism in academic year 2017/2018 with contribution of $66.1 \%$.
\end{abstract}

Keywords: Interest In Learning; Emotional Intelligence; Statistical Learning Outcomes 
PEDAGOGIA : Jurnal Ilmu Pendidikan

\section{A. PENDAhULUAN}

Salah satu indikator keberhasilan suatu pembelajaran dapat dilihat dari hasil belajar siswa. Hasil belajar merupakan hasil dari suatu interaksi tindak belajar dan tindak mengajar. Dari sisi guru, tindak mengajar diakhiri dengan proses evaluasi hasil belajar. Dari sisi siswa, hasil belajar merupakan berakhirnya penggal dan puncak proses belajar (Dimyati dan Mudjiono, 2013). Setelah suatu proses belajar berakhir, maka siswa memperoleh suatu hasil belajar. Hasil belajar mempunyai peranan penting dalam proses pembelajaran. Hasil belajar digunakan untuk mengetahui sebatas mana siswa dapat memahami serta mengerti materi tersebut

Tinggi rendahnya hasil belajar siswa dipengaruhi oleh beberapa faktor. Faktor-faktor yang mempengaruhi hasil belajar terdiri dari faktor internal dan eksternal. Faktor internal merupakan faktor yang berasal dari dalam diri siswa seperti kecerdasan, motivasi, disiplin dan minat. Sedangkan faktor eksternal merupakan faktor yang berasal dari luar diri siswa seperti lingkungan, guru, sarana dan prasarana belajar. Kesemua faktor tersebut saling mempengaruhi dan mendukung dalam pencapaian hasil belajar siswa yang optimal (Djamarah, 2011).

Keberhasilan pembelajaran siswa dapat dilihat dari nilai hasil belajar yang diperoleh selama kurun waktu tertentu. Dalam mata kuliah statistik di perguruan tinggi, keberhasilan pembelajaran dapat dilihat dari nilai hasil belajar statistik mahasiswa selama satu semester. Tinggi rendahnya nilai hasil belajar statistik yang diperoleh mahasiswa dipengaruhi oleh dua faktor yaitu faktor internal dan eksternal (Muhibbin, Syah, 2011). Beberapa faktor internal yang diduga mempengaruhi hasil belajar statistik adalah minat belajar dan kecerdasan emosional siswa.

Minat belajar diartikan sebagai suatu kondisi yang terjadi apabila seseorang melihat ciri-ciri atau arti sementara situasi yang dihubungkan dengan keinginan-keinginan atau kebutuhannya sendiri (Sardiman, 2011). Oleh karena itu, apa yang dilihat seseorang sudah tentu akan membangkitkan minatnya sejauh apa yang dilihat itu mempunyai hubungan dengan kepentingannya sendiri. Hal ini menunjukkan bahwa minat merupakan kecenderungan jiwa seseorang kepada seseorang (bisanya disertai dengan perasaan senang), karena merasa ada kepentingan dengan sesuatu itu.

Minat belajar besar pengaruhnya terhadap aktivitas belajar mahasiswa, sebab dengan minat seseorang akan melakukan sesuatu yang diminatinya. Sebaliknya tanpa minat, seseorang tidak mungkin melakukan sesuatu (Usman, Husaini, 2013). Mahasiswa yang berminat terhadap mata kuliah statistik akan mempelajari statistik dengan sungguhsungguh seperti rajin belajar, merasa 
PEDAGOGIA : Jurnal Ilmu Pendidikan

senang mengikuti perkuliahan statistik, dan bahkan dapat menemukan kesulitan-kesulitan dalam belajar menyelesaikan soal-soal latihan karena adanya daya tarik yang diperoleh dengan mempelajari statistik. Proses belajar akan berjalan lancar bila disertai minat belajar yang tinggi. Oleh karena itu, dosen perlu membangkitkan minat mahasiswa agar perkuliahan yang diberikan mudah dimengerti oleh mahasiswa.

Selain minat belajar, faktor internal yang mempengaruhi hasil belajar adalah kecerdasan emosional. Kecerdasan emosional adalah kemampuan untuk mengenali perasaan sendiri dan perasaan orang lain, kemampuan memotivasi diri sendiri, dan kemampuan mengelola emosi dengan baik pada diri sendiri dan dalam hubungannya dengan orang lain (Goleman, 2004). Kecerdasan emosional akan melahirkan seseorang menjadi pribadi yang bijaksana, mampu mengontrol diri dan peka terhadap lingkungan sekitar. Kecerdasan emosional mampu mengoptimalkan potensi dalam peserta didik sehingga prestasi belajar peserta didik lebih meningkat.

Menurut Goleman (2004), khusus pada orang-orang yang murni hanya memiliki kecerdasan akademis tinggi, mereka cenderung memiliki rasa gelisah yang tidak beralasan, terlalu kritis, rewel, cenderung menarik diri, terkesan dingin dan cenderung sulit mengekspresikan kekesalan dan kemarahannya secara tepat.
Bila didukung dengan rendahnya taraf kecerdasan emosionalnya, maka orangorang seperti ini sering menjadi sumber masalah. Karena sifat-sifat di atas, bila seseorang memiliki IQ tinggi namun taraf kecerdasan emosionalnya rendah maka cenderung akan terlihat sebagai orang yang keras kepala, sulit bergaul, mudah frustrasi, tidak mudah percaya kepada orang lain, tidak peka dengan kondisi lingkungan dan cenderung putus asa bila mengalami stress. Kondisi sebaliknya, dialami oleh orang-orang yang memiliki taraf IQ rata-rata namun memiliki kecerdasan emosional yang tinggi.

Berdasarkan pemaparan tersebut, maka dalam konteks penelitian ini akan diinvestigasi 2 faktor internal yang mempengaruhi hasil belajar siswa yaitu minat belajar dan kecerdasan emosional siswa. Melalui penelitian ini diharapkan kontribusi kedua variabel itu dapat dibuktikan secara empiris terhadap hasil belajar statistik mahasiswa.

Adapun rumusan masalah dalam penelitian ini adalah sebagai berikut. Pertama, seberapa besar kontribusi minat belajar terhadap hasil belajar statistik mahasiswa MFB semester 6 Sekolah Tinggi Pariwisata Triatma Jaya tahun pelajaran 2017/2018? Kedua, seberapa besar kontribusi kecerdasan emosional mahasiswa terhadap hasil belajar statistik mahasiswa MFB semester 6 Sekolah Tinggi Pariwisata Triatma Jaya tahun pelajaran 2017/2018? Ketiga, seberapa besar kontribusi secara bersama-sama 
minat belajar dan kecerdasan emosional mahasiswa terhadap hasil belajar statistik mahasiswa MFB semester 6 Sekolah Tinggi Pariwisata Triatma Jaya tahun pelajaran 2017/2018?

Dari permasalahan tersebut, maka tujuan penelitian ini adalah sebagai berikut. Pertama, untuk mengetahui dan menganalisis besaran kontribusi minat belajar terhadap hasil belajar statistik mahasiswa MFB semester 6 Sekolah Tinggi Pariwisata Triatma Jaya tahun pelajaran 2017/2018. Kedua, untuk mengetahui dan menganalisis besaran kontribusi kecerdasan emosional mahasiswa terhadap hasil belajar statistik mahasiswa MFB semester 6 Sekolah Tinggi Pariwisata Triatma Jaya tahun pelajaran 2017/2018. Ketiga, untuk mengetahui dan menganalisis besaran kontribusi secara bersama-sama minat belajar dan kecerdasan emosional mahasiswa terhadap hasil belajar statistik mahasiswa MFB semester 6 Sekolah Tinggi Pariwisata Triatma Jaya tahun pelajaran 2017/2018.

\section{B. TINJAUAN PUSTAKA}

\section{Minat Belajar}

Poerwanto (2010) mengatakan bahwa minat merupakan landasan penting bagi seseorang untuk melakukan kegiatan dengan baik yaitu dorongan seseorang untuk berbuat. Djamarah (2011) mengatakan minat adalah suatu rasa lebih suka dan rasa keterikatan pada suatu hal atau aktivitas tanpa ada yang menyuruh. Sedangkan Slameto (2010) mengatakan minat adalah penerimaan akan sesuatu hubungan antara diri sendiri dengan sesuatu di luar diri.

Berdasarkan pendapat di atas, dapat disimpulkan bahwa minat adalah suatu keinginan dalam diri manusia untuk melakukan suatu kegiatan. Minat belajar sangat berperan penting dalam proses pembelajaran. Semakin tinggi minat belajar siswa, maka proses pembelajaran akan semakin baik. Sebaliknya, jika minat belajar siswa rendah, maka akan mengganggu proses pembelajaran.

Menurut Slameto (2010) beberapa indikator minat belajar adalah sebagai berikut. (1) Perasaan senang, apabila seorang siswa memiliki perasaan senang terhadap pelajaran tertentu maka tidak akan ada rasa terpaksa untuk belajar. Contohnya yaitu senang mengikuti pelajaran, tidak ada perasaan bosan, dan hadir saat pelajaran. (2) Keterlibatan siswa, ketertarikan seseorang akan obyek yang mengakibatkan orang tersebut senang dan tertarik untuk melakukan atau mengerjakan kegiatan dari obyek tersebut. Contoh: aktif dalam diskusi, aktif bertanya, dan aktif menjawab pertanyaan dari guru. (3) Ketertarikan, berhubungan dengan daya dorong siswa terhadap ketertarikan pada sesuatu benda, orang, kegiatan atau bisa berupa pengalaman afektif yang dirangsang oleh kegiatan itu sendiri. Contoh: antusias dalam mengikuti pelajaran, tidak menunda tugas dari dosen. 
PEDAGOGIA : Jurnal Ilmu Pendidikan

(4) Perhatian siswa, minat dan perhatian merupakan dua hal yang dianggap sama dalam penggunaan sehari-hari, perhatian siswa merupakan konsentrasi siswa terhadap pengamatan dan pengertian, dengan mengesampingkan yang lain. Siswa memiliki minat pada obyek tertentu maka dengan sendirinya akan memperhatikan obyek tersebut. Contoh: mendengarkan penjelasan dosen dan mencatat materi.

\section{Kecerdasan Emosional}

Kecerdasan emosional adalah kemampuan untuk mengenali perasaan sendiri dan perasaan orang lain, kemampuan memotivasi diri sendiri, dan kemampuan mengelola emosi dengan baik pada diri sendiri dan dalam hubungannya dengan orang lain (Goleman, 2004). Kecerdasan emosional adalah penggunaan emosi untuk mengendalikan situasi (Khokhar \& Kush, 2009). Tingkat kecerdasan emosional orang-orang menjadi lebih baik pada saat mereka mahir dalam menangani emosi, memotivasi diri mereka sendiri (Natalie, dkk, 2010). Kecerdasan emosional sangat dipengaruhi oleh lingkungan, tidak bersifat menetap, dapat berubah-ubah setiap saat. Untuk itu peranan lingkungan terutama orang tua pada masa kanakkanak sangat mempengaruhi dalam pembentukan kecerdasan emosional.

Ciri-ciri seseorang memiliki kecerdasan emosional yang baik adalah sebagai berikut. (1) Kesadaran diri: mengetahui apa yang dirasakan suatu saat dan menggunakannya untuk mengambil keputusan diri sendiri, memiliki tolok ukur yang realistis atas kemampuan sendiri dan kepercayaan diri yang kuat. (2) Mengelola emosi: kemampuan menangani emosi sedemikian sehingga berdampak positif terhadap pelaksanaan tugas, peka terhadap kata hati dan sanggup menunda kenikmatan sebelum tercapainya suatu sasaran, mampu pulih kembali dari tekanan emosi. (3) Motivasi diri: menggunakan harsat yang paling dalam untuk menggerakkan dan menuntun menuju sasaran, mengambil inisiatif dan bertindak sangat efektif, dan untuk bertahan menghadapi kegagalan dan frustasi. (4) Empati diri: merasakan yang dirasakan orang lain, memahami perspektif orang lain, menumbuhkan hubungan saling percaya dan menyelaraskan diri dengan bermacammacam orang. (5) Keterampilan sosial: menggunakan keterampilan-keterampilan sosial untuk mempengaruhi dan memimpin, bermusyawarah dan menyelesaikan perselisihan, dan untuk bekerja sama dalam tim (Goleman, 2004).

\section{Hasil Belajar Statistik}

Hasil belajar adalah pola-pola perbuatan, nilai-nilai, pengertianpengertian, sikap-sikap, apresiasi, dan keterampilan-keterampilan (Suprijono, 2009). Hasil belajar adalah hasil yang diperoleh siswa setelah mengalami proses 
PEDAGOGIA : Jurnal Ilmu Pendidikan

pembelajaran (Oktaviani, 2014). Proses pembelajaran yang dimaksud adalah proses ketika seorang siswa memperoleh pemahaman akan suatu hal yang sebelumnya ia tidak mengerti menjadi mengerti. Hasil belajar merupakan hasil dari suatu interaksi tindak belajar dan tindak mengajar. Dari sisi guru, tindak mengajar diakhiri dengan proses evaluasi hasil belajar. Dari sisi siswa, hasil belajar merupakan berakhirnya penggal dan puncak proses belajar (Dimyati dan Mudjiono, 2013). Sedangkan yang dimaksud hasil belajar statistik yaitu suatu indikator untuk mengukur keberhasilan siswa dalam proses pembelajaran statistik.

Faktor-faktor yang mempengaruhi hasil belajar terdiri dari faktor internal dan eksternal. Faktor internal merupakan faktor yang berasal dari dalam diri siswa seperti kecerdasan, motivasi, disiplin dan minat. Sedangkan faktor eksternal merupakan faktor yang berasal dari luar diri siswa seperti lingkungan, guru, sarana dan prasarana belajar. Kesemua faktor tersebut saling mempengaruhi dan mendukung dalam pencapaian hasil belajar siswa yang optimal (Djamarah, 2011).

\section{METODE PENELITIAN}

Penelitian ini tergolong penelitian ex-post facto. Penelitian ini menggunakan pendekatan kuantitatif dengan rancangan korelasional karena dalam penelitian ini mencoba mengetahui hubungan antar variabel yang dikorelasikan.

Populasi dalam penelitian ini adalah seluruh mahasiswa D III Perhotelan semester 6 Sekolah Tinggi Pariwisata Triatma Jaya Tahun Pelajaran 2017/2018 yang berjumla 77 orang. Mahasiswa D III Perhotelan ini terdiri dari tiga kelas yaitu Manajemen Akomodasi Perhotelan (MAP), Manajemen Food and Beverage (MFB A), dan MFB B. Teknik pengambilan sampel dalam penelitian ini menggunakan sampel jenuh dimana semua populasi dijadikan sampel penelitian. Maka dari itu, sampel dalam penelitian ini berjumlah 77 orang.

Vaiabel dalam penelitian ini terdiri dari dua (2) variabel bebas dan satu (1) variabel terikat. Variabel bebas dalam penelitian ini adalah minat belajar $\left(\mathrm{X}_{1}\right)$ dan kecerdasan emosional $\left(\mathrm{X}_{2}\right)$. Sedangkan variabel terikat dalam penelitian ini adalah hasil belajar statistik (Y). Variabel minat belajar dan kecerdasan emosional diukur dengan menggunakan instrumen penelitian berupa kuesioner. Sedangkan variabel hasil belajar statistik diukur dengan menggunakan tes hasil belajar statistik yang berupa pilihan ganda.

Sebelum instrumen penelitan digunakan, maka terlebih dahulu harus dilakukan validasi instrumen penelitian. Instrumen minat belajar dan kecerdasan emosional dicari nilai validitas butir instrumen dengan menggunakan rumus Product Moment dan reliabilitas tes dengan menggunakan rumus Alpha 
PEDAGOGIA : Jurnal Ilmu Pendidikan

Cronbach. Sedangkan untuk hasil belajar dicari nilai validitas butir dengan menggunakan rumus Point Biserial dan reliabilitas tes dengan menggunakan rumus $K R-21$.

Analisis data yang digunakan dalam penelitian ini adalah analisis regresi linier berganda. Sebelum data dianalisis dengan menggunakan analisis regresi linier berganda, maka terlebih dahulu data harus memenuhi uji asumsi klasik. Adapun uji asumsi klasik yang harus dipenuhi yaitu uji normalitas sebaran data, uji multikolinieritas, dan uji heteroskedastisitas. Uji normalitas sebaran data dihitung dengan menggunakan Kolmogorov Smirnov. Uji multikolinieritas dapat dihitung dengan melihat nilai tolerance lebih besar dari 0,1 dan nilai VIF kurang dari 10. Sedangkan uji heteroskedastisitas dihitung dengan metode Glejser. Dalam penelitian ini, semua perhitungan analisis data dicari dengan menggunakan aplikasi SPSS 22.

\section{HASIL DAN PEMBAHASAN}

Sebelum instrumen digunakan dalam penelitian, maka terlebih dahulu instrumen penelitian diuji cobakan terhadap 60 responden untuk mengetahui apakah instrumen tersebut layak digunakan untuk penelitian. Berdasarkan hasil analisis validitas butir, maka dapat disimpulkan bahwa semua butir dikatakan valid karena nilai korelasinya di atas 0,3. Sedangkan untuk nilai reliabilitas untuk semua instrumen berada di atas angka 0,6 sehingga instrumen dikatakan reliabel. Setelah memenuhi uji validitas dan reliabilitas, maka instrumen ketiga variabel dapat digunakan dalam penelitian.

Bedasarkan hasil analisis data, dapat diketahui bahwa semua data telah memenuhi uji asumsi klasik. Uji asumsi klasik dalam penelitian ini adalah sebagai berikut. (1) Uji normalitas sebaran data, berdasarkan hasil analisis data dengan menggunakan SPSS 22 dapat diketahui bahwa nilai Kolmogorov Smirnov untuk variabel minat belajar $\left(\mathrm{X}_{1}\right)$ sebesar 0,199; kecerdasan emosional $\left(\mathrm{X}_{2}\right)$ sebesar 0,098; dan hasil belajar (Y) sebesar 0,089. Dari hasil tersebut, dapat dilihat bahwa semua nilai Kolmogorov Smirnov di atas 0,05 ini berarti bahwa semua data berdistribusi normal. (2) Uji Multikolinieritas, berdasarkan hasil analisis data dapat diketahui bahwa nilai Tolerance sebesar 0,877 dan nilai VIF sebesar 1,140. Ini berarti bahwa nilai Tolerance lebih besar dari 0,1 dan nilai VIF kurang dari 10, maka dari itu dapat disimpulkan bahwa tidak terjadi multikolinieritas antar variabel bebas. (3) Uji heteroskedastisitas, berdasarkan hasil analisis data dapat diketahui bahwa nilai sig untuk $\mathrm{X}_{1}$ sebesar 0,873 dan $X_{2}$ sebesar 914. Nilai signifikansi untuk semua variabel di atas 0,05, maka dari itu dapat disimpulkan bahwa tidak terjadi heteroskedastisitas.

Setelah memenuhi uji asumsi klasik, kemudian data diolah dengan 
PEDAGOGIA : Jurnal Ilmu Pendidikan

menggunakan analisis regresi linier berganda. Berdasarkan hasil analisis data, maka didapat persamaan garis regresi $\hat{Y}=$ $19,309+0,622\left(X_{1}\right)+0,393\left(X_{2}\right)$. Adapun hasil analisis regresi linier berganda dapat dilihat pada ringkasan tabel 1 berikut ini.

Tabel 1

Ringkasan Hasil Uji Hipotesis Penelitian

\begin{tabular}{lccccc}
\hline \multirow{2}{*}{$\begin{array}{l}\text { Hubungan } \\
\text { Variabel }\end{array}$} & \multicolumn{2}{c}{ Nilai t } & \multicolumn{2}{c}{ Nilai $\mathrm{F}$} & \multicolumn{2}{c}{ Kontribusi } \\
\cline { 2 - 6 } & t-hitung & sig & F-hitung & sig & \\
\hline $\mathrm{X}_{1}$ terhadap Y & 8,231 & 0,000 & - & - & $52,9 \%$ \\
\hline $\mathrm{X}_{2}$ terhadap Y & 5,622 & 0,000 & - & - & $36,8 \%$ \\
\hline $\mathrm{X}_{1}$ dan $\mathrm{X}_{2}$ & - & - & 75,170 & 0,000 & $66,1 \%$ \\
terhadap Y & & & \multicolumn{2}{c}{} \\
\hline
\end{tabular}

Berdasarkan tabel 1 di atas dapat diketahui bahwa nilai probabilitas $X_{1}$ terhadap Y sebesar 0,000 yang mana lebih kecil daripada 0,05 Ini berarti bahwa hipotesis pertama yang menyatakan bahwa terdapat kontribusi yang signifikan minat belajar $\left(\mathrm{X}_{1}\right)$ terhadap hasil belajar statistik mahasiswa semester 6 program D III Perhotelan di Sekolah Tinggi Pariwisata Triatma Jaya diterima. Variabel minat belajar berkontribusi sebesar 52,9 \% terhadap hasil belajar statistik mahasiswa semester 6 program D III Perhotelan di Sekolah Tinggi Pariwisata Triatma Jaya.

Hasil penelitian ini didukung oleh penelitian sebelumnya yang dilakukan oleh Sukada (2013) dengan judul "Kontribusi Minat Belajar, Motivasi Berprestasi dan Kecerdasan Logis Matematika Terhadap Hasil Belajar Matematika Siswa SMA Negeri 1 Kintamani". Hasil penelitian ini menunjukkan bahwa secara terpisah atau bersama-sama terdapat kontribusi signifikan antara minat, motivasi berprestasi, dan kecerdasan logis matematika terhadap hasil belajar matematika siswa Kelas XI Jurusan IPA, IPB, dan IPS SMA Negeri 1 Kintamani. Selain itu penelitian yang dilakukan oleh Rusmiati (2017) dengan judul "Pengaruh Minat Belajar Terhadap Prestasi Belajar Bidang Studi Ekonomi Siswa MA Al Fattah Sumbermulyo". Hasil penelitian ini menunjukkan bahwa minat belajar pelajaran ekonomi mempunyai pengaruh yang sedang atau cukup terhadap prestasi belajar bidang studi ekonomi siswa Madrasah Aliyah Al Fattah Sumbermulyo.

Hasil penelitian ini juga didukung oleh beberapa teori yang dikemukakan oleh para ahli. Djamarah (2011) mengatakan minat adalah suatu rasa lebih suka dan rasa keterikatan pada suatu hal atau aktivitas tanpa ada yang menyuruh. Minat belajar besar pengaruhnya terhadap aktivitas belajar mahasiswa, sebab dengan minat seseorang akan melakukan sesuatu yang diminatinya. Sebaliknya tanpa minat, seseorang tidak mungkin melakukan sesuatu (Usman, Husaini, 2013). Minat belajar sangat berperan penting dalam proses pembelajaran. Semakin tinggi minat belajar siswa, maka proses pembelajaran akan semakin baik. Sebaliknya, jika minat belajar siswa rendah, maka akan mengganggu proses pembelajaran.

Slameto (2010) mengatakan bahwa mengembangkan minat terhadap sesuatu pada dasarnya adalah membantu siswa 
PEDAGOGIA : Jurnal Ilmu Pendidikan

melihat bagaimana hubungan antara materi yang diharapkan untuk dipelajarinya dengan dirinya sendiri sebagai individu. Proses ini berarti menunjukkan pada siswa bagaimana pengetahuan atau kecakapan tertentu mempengaruhi dirinya, melayani tujuantujuannya, memuaskan kebutuhannya. Bila siswa menyadari bahwa belajar merupakan suatu alat untuk mencapai beberapa tujuan yang dianggapnya penting, dan bila siswa melihat bahwa hasil dari pengalaman belajarnya akan membawa kemajuan pada dirinya kemungkinan besar ia akan berminat dan termotivasi untuk mempelajarinya.

Berdasarkan tabel 1 di atas dapat diketahui bahwa nilai probabilitas $\mathrm{X}_{2}$ terhadap Y sebesar 0,000 yang mana lebih kecil daripada 0,05 Ini berarti bahwa hipotesis kedua yang menyatakan bahwa terdapat kontribusi yang signifikan kecerdasan emosional $\left(\mathrm{X}_{2}\right)$ terhadap hasil belajar statistik mahasiswa semester 6 program D III Perhotelan di Sekolah Tinggi Pariwisata Triatma Jaya diterima. Variabel kecerdasan emosional berkontribusi sebesar 36,8 \% terhadap hasil belajar statistik mahasiswa semester 6 program D III Perhotelan di Sekolah Tinggi Pariwisata Triatma Jaya.

Hasil penelitian ini didukung oleh penelitian sebelumnya yang dilakukan oleh Defila, dkk (2014) dengan judul "Hubungan Kecerdasan Emosional dengan Hasil Belajar IPA Siswa SMP
Negeri 1 Palu". Hasil penelitian ini menunjukkan bahwa kecerdasan emosional berkontribusi sebesar 31,25\% terhadap hasil belajar IPA siswa SMP Negeri 1 Palu. Selain itu, hasil penelitian ini juga didukung oleh penelitian yang dilakukan oleh Baghdad Afero, Adman (2016) dengan judul "Peran Kecerdasan Emosional Sebagai Faktor yang Mempengaruhi Kemandirian Belajar Siswa". Hasil penelitian ini menunjukkan bahwa kecerdasan emosional memiliki pengaruh yang positif dan signifikan terhadap kemandirian belajar siswa.

Hasil penelitian ini juga didukung oleh beberapa teori yang dikemukakan oleh para ahli. Khoerunisa (2011) mengatakan bahwa seseorang dengan kemampuan kecerdasan emosional tinggi akan mampu mengenal dirinya sendiri dan menggunakan informasi untuk membimbing pikiran dan tindakan sehingga berpengaruh dengan suasana perasaannya dalam melakukan kegiatan. Kecerdasan emosi memiliki kontribusi yang unik untuk memahami hubungan antara tingkat stres seseorang dan kesehatan mentalnya dan menyumbang sebesar $80 \%$ bagi kesuksesan seseorang (Metsi, 2010).

Berdasarkan tabel 1 di atas dapat diketahui bahwa nilai probabilitas $X_{1}$ dan $\mathrm{X}_{2}$ terhadap $\mathrm{Y}$ sebesar 0,000 yang mana lebih kecil daripada 0,05 Ini berarti bahwa hipotesis ketiga yang menyatakan bahwa terdapat kontribusi yang signifikan secara bersama-sama minat belajar $\left(\mathrm{X}_{1}\right)$ dan 
PEDAGOGIA : Jurnal Ilmu Pendidikan

kecerdasan emosional $\left(\mathrm{X}_{2}\right)$ terhadap hasil belajar statistik mahasiswa semester 6 program D III Perhotelan di Sekolah Tinggi Pariwisata Triatma Jaya diterima. Variabel minat belajar dan kecerdasan emosional secara bersama-sama berkontribusi sebesar 66,1 \% terhadap hasil belajar statistik mahasiswa semester 6 program D III Perhotelan di Sekolah Tinggi Pariwisata Triatma Jaya.

Apabila secara terpisah minat belajar dan kecerdasan emosional berkontribusi terhadap hasil belajar statistik mahasiswa, maka secara bersama-sama juga akan berkontribusi terhadap hasil belajar statistik mahasiswa D III Perhotelan Sekolah Tinggi Pariwisata Triatma Jaya. Seorang mahasiswa yang memiliki minat belajar yang tinggi serta didukung oleh kecerdasan emosional yang baik, maka akan memiliki hasil belajar yang baik pula. Maka dari itu, kesuksesan suatu pembelajaran tidak hanya ditentukan oleh faktor eksternal saja, akan tetapi juga faktor internal dari dalam diri siswa (Djamarah, 2011).

\section{E. KESIMPULAN}

Berdasarkan hasil analisis data dan pembahasan di atas, maka simpulan dalam penelitian ini adalah sebagai berikut. Pertama, terdapat kontribusi yang signifikan minat belajar terhadap hasil belajar statistik mahasiswa semester 6 program D III Perhotelan Sekolah Tinggi
Pariwisata Triatma Jaya tahun pelajaran 2017/2018. Minat belajar berkontribusi sebesar 52,9 \% terhadap hasil belajar statistik. Kedua, terdapat kontribusi yang signifikan kecerdasan emosional terhadap hasil belajar statistik mahasiswa semester 6 program D III Perhotelan Sekolah Tinggi Pariwisata Triatma Jaya tahun pelajaran 2017/2018. Kecerdasan emosional berkontribusi sebesar 36,8 \% terhadap hasil belajar statistik. Ketiga, terdapat kontribusi yang signifikan secara bersama-sama minat belajar dan kecerdasan emosional terhadap hasil belajar statistik mahasiswa semester 6 program D III Perhotelan Sekolah Tinggi Pariwisata Triatma Jaya tahun pelajaran 2017/2018. Minat belajar dan kecerdasan emosional secara bersama-sama berkontribusi sebesar 66,1 \% terhadap hasil belajar statistik.

\section{DAFTAR PUSTAKA}

Baghdad Afero, Adman. (2016). Peran Kecerdasan Emosional Sebagai Faktor yang Mempengaruhi Kemandirian Belajar Siswa. Jurnal Pendidikan Manajemen Perkantoran, Volume 1, Nomor 1. Defila, dkk (2014). Hubungan Kecerdasan Emosional dengan Hasil Belajar IPA Siswa SMP Negeri 1 Palu. Jurnal Pendidikan Fisika Tadulako (JPFT), Vol. 2, No. 2.

Dimyati dan Mudjiono. (2013). Belajar dan Pembelajaran. Jakarta: Rineka 
PEDAGOGIA : Jurnal Ilmu Pendidikan

Cipta.

Djamarah, S. B. (2011). Psikologi Belajar. Jakarta: Rineka Cipta.

Goleman, Daniel. (2004). Emitional Intelligence Kecerdasan Emosional Mengapa EQ Lebih Penting Daripada IQ. Jakata: PT Gramedia Pustaka Utama.

Khoerunisa. (2011). Pengaruh

Kecerdasan Emosional Siswa terhadap Akhlak Siswa (Penelitian di Kelas V SD Negeri Pakuwon II Kota Garut). Jurnal Pendidikan Universitas Garut, Volume 5, Nomor 1, 30-43.

Khokhar, C. P., \& Kush, T. (2009). Emotional Intelligence and Work Performance among Executives. Europe's Journal of Psychology, 111.

Metsi, D. (2010). Pengaruh Kecerdasan Emosional terhadap Prestasi Belajar Mahasiswa Jurusan Pendidikan Teknik Bangunan Fakultas Teknik Universitas Negeri Manado. Jurnal Pendidikan Teknologi dan Kejuruan, Volume 1, Nomor 1, 1-7.

Muhibbin, Syah. (2011). Psikologi Belajar. Jakarta: Bumi Aksara.

Natalie, dkk. (2010). The effect of emotional intelligence, age, work, experience, and academic performance. Research in Higher Education Journal, 1-18.

Oktaviani, Laras. (2014). Pengaruh Model Problem Based
Learning Berbasis Asesmen Kinerja Terhadap Hasil Belajar IPA Ditinjau Dari Gaya Kognitif. e-jurnal Penelitian dan Evaluasi Pendidikan Pascasarjana UNDIKSHA, Volume 4.

Poerwanto, N. (2010). Psikologi Pendidikan. Bandung: Remaja Rosdakarya.

Rusmiati. (2017). Pengaruh Minat Belajar Terhadap Prestasi Belajar Bidang Studi Ekonomi Siswa MA Al Fattah Sumbermulyo. Jurnal ilmiah Pendidikan dan Ekonomi, Volume 1, Nomor 1.

Sardiman. (2011). Interaksi dan Motivasi Belajar Mengajar. Jakarta: Rajawali Press.

Slameto. (2010). Belajar dan Faktorfaktor yang Mempengaruhinya. Jakarta: Rineka Cipta.

Sukada. (2013). Kontribusi Minat Belajar, Motivasi Berprestasi dan Kecerdasan Logis Matematika Terhadap Hasil Belajar Matematika Siswa SMA Negeri 1 Kintamani. e-Journal Program Studi Administrasi Pendidikan Program Pascasarjana Universitas Pendidikan Ganesha, Volume 4.

Suprijono, Agus. (2009). Cooperatif Learning Teori dan Aplikasi PAIKEM. Yogyakarta: Pustaka Pelajar. 
PEDAGOGIA : Jurnal Ilmu Pendidikan

Usman, Husaini. (2013). Manajemen

Teori, Praktik, dan Riset

Pendidikan Edisi Keempat.

Jakarta Timur: Bumi Aksara. 